\title{
A 'Core Periphery' Framework to Navigate Emerging Market Governments-Qualitative Evidence from a Biotechnology Multinational
}

\section{Citation}

Choudhury, Prithwiraj, James Geraghty, and Tarun Khanna. "A 'Core Periphery' Framework to Navigate Emerging Market Governments-Qualitative Evidence from a Biotechnology Multinational." Global Strategy Journal 2, no. 1 (February 2012): 71-87.

\section{Published Version}

http://onlinelibrary.wiley.com/doi/10.1002/gsj.1021/full

\section{Permanent link}

http://nrs.harvard.edu/urn-3:HUL.InstRepos:28538427

\section{Terms of Use}

This article was downloaded from Harvard University's DASH repository, and is made available under the terms and conditions applicable to Other Posted Material, as set forth at http:// nrs.harvard.edu/urn-3:HUL.InstRepos:dash.current.terms-of-use\#LAA

\section{Share Your Story}

The Harvard community has made this article openly available.

Please share how this access benefits you. Submit a story.

\section{Accessibility}


Running head: A Core-Periphery Framework to Navigate Emerging Market Governments

\section{A 'CORE-PERIPHERY' FRAMEWORK TO NAVIGATE EMERGING MARKET GOVERNMENTS-QUALITATIVE EVIDENCE FROM A BIOTECHNOLOGY MULTINATIONAL}

Prithwiraj Choudhury,,$^{*}$ James A. Geraghty, ${ }^{2}$ Tarun Khanna ${ }^{3}$

${ }^{1}$ The Wharton School, University of Pennsylvania, Philadelphia, Pennsylvania, U.S.A

${ }^{2}$ Genzyme Corporation, Cambridge, Massachusetts, U.S.A.

${ }^{3}$ Harvard Business School, Harvard University, Boston, Massachusetts, U.S.A.

Keywords:

*Correspondence to: Prithwiraj Choudhury, The Wharton School, University of Pennsylvania, 2025 SH-DH, 3620 Locust Walk, Philadelphia, PA 19104, U.S.A. E-mail:

prithw@wharton.upenn.edu

We build on the emerging literature of influence-based models to study how multinational firms can navigate host governments. Our 'core-periphery' framework posits that the actions that an MNC takes with actors in what we call the 'periphery'-comprised of state, quasi-state, and civil society actors - can lead to positive or negative influence with interconnected state actors in a 'core.' There are two mechanisms by which this can happen: engaging the periphery may either change the information set of the core or help align incentives of multiple core actors. Engaging the periphery might be particularly relevant in settings where the institutional framework is still emerging. We build a case study of a multinational firm in the biotechnology sector to illustrate how the core-periphery framework works in multiple emerging markets across institutional differences. The analysis is based on 32 interviews conducted with the CEO and other executives of Genzyme at the corporate headquarters in Cambridge, Massachusetts, and in subsidiaries in Brazil, China, Costa Rica, France, India, and the United States. Copyright $\odot 2012$ Strategic Management Society. 


\section{INTRODUCTION}

The government is not only a prime actor in the global business environment, its footprint is ever more important post the current financial crisis (Reich 2009). Across several emerging markets, the role of the state in business is ubiquitous, and recent papers suggest that the involvement of state actors in business has increased over the years, even in the face of ambitious privatization programs across several emerging markets. ${ }^{1}$ An excellent survey of the SOE privatization and reform literature is provided by Megginson and Netter (2001). ${ }^{2}$

Multinational firms (MNCs) not only interact with multiple state actors, but they also interact with actors from civil society that are related directly or indirectly to state actors. The international business literature has had a long tradition of studying how MNCs should deal with host governments. ${ }^{3}$ However, until recently, this literature did not account for the disaggregated nature of the government and how interdependencies among government actors affect the MNChost government relationship.

There is an emerging body of work in political science and international business that attempts to fill this gap. Witold Henisz, Bennet Zelner, and other scholars study the disaggregated nature of the government and use influence-based models in framing the MNCgovernment relationship. This body of work builds on the dynamic expected utility decision process developed by Bruce Bueno de Mesquita in the 1980s and subsequent work by Pablo Spiller and Mariano Tommasi since the 1990s.

\footnotetext{
${ }^{1}$ Choudhury and Khanna (2010) analyze the involvement of the state in business in the context of India. The authors show that in 2007, 30 percent of firm sales in India were with state-owned firms. This was an increase from the 27 percent share of sales that state-owned entities (SOEs) had in 1991, the year the ambitious Indian SOE privatization program was initiated. ${ }^{2}$ Dastidar, Fisman, and Khanna (2008) document why privatization of SOEs, in many cases, have been partial in nature.

${ }^{3}$ Papers in this area include Caves (1996), Dunning (1998), and Boddewyn (1998). Boddewyn (2005) has a summary-related chapter in the book edited by Robert Grosse.
} 
Our 'core-periphery' framework builds on these foundations and studies interactions between a multinational firm and host governments. We have two research questions. First, we are interested in studying whether MNCs that do not have direct access to core government actors can, instead, leverage peripheral actors to influence the core. Second, we are interested in understanding the mechanisms through which the peripheral actors can influence the core.

There are several key tenets of our framework. Building on the veto points core literature in political science (Tsebelis 1995), we posit that the government landscape comprises two sets of actors: (1) those who can veto the policy decision in question and (2) those who cannot veto the decision but are able to influence actors who have the veto rights. We use the terminology 'veto points core' to designate state actors that are directly involved in policy setting. We also use the terminology 'periphery of influence' to designate state, quasi-state, and even civil society actors that may not be directly involved in policy setting but can influence the core actors. We then posit that the actions an MNC takes with an actor or a set of actors in the periphery can lead to positive or negative influence in the core. We also hypothesize that there are two mechanisms by which actors in the periphery can influence actors in the core: (1) by changing the information set of the core actors and (2) by aligning the incentives of multiple core actors with the interests of the MNC in question.

A central feature of our framework is that in addition to considering pure state actors, we also consider quasi-state actors, i.e., actors that are only indirectly related to the state, possibly through funding. We also consider civil society actors who may be influential in shaping decision making by core government actors. We also posit that the value in engaging peripheral actors is particularly salient in environments where the institutional framework is still evolving 
and where core government actors lack complete information vis-à-vis the policy decision in question.

We illustrate the 'core-periphery' framework using a clinical study of Genzyme, a global biotechnology firm. Using case studies from Brazil, China, and Costa Rica, we document how the core-periphery framework works across institutional differences in multiple emerging markets.

\section{THE MNC-GOVERNMENT RELATIONSHIP: INFLUENCE BASED MODELS}

In this paper, we attempt to integrate insights from multiple literatures - the literature in international business on how firms should deal with host governments and the literature on public policy in political science and economics. We particularly draw upon an emerging literature that uses influence-based models in framing firm-government relationships.

\section{Prior literature in international business}

There is a rich literature in international business that studies interactions between multinational firms (MNCs) and host governments. Dunning (1998) documents the historically hostile relationships between MNCs and host governments, especially in emerging markets. He states that countries in Latin America were particularly concerned about the negative effects of foreign investment on sovereignty. One of the seminal pieces in this literature is by Richard Caves (1996) and is presented in Chapter 10 of his book Multinational Enterprise and Economic Analysis. He adopts a neoclassical welfare economics approach to study interactions between MNCs and host governments and states that government officials resent MNCs because of their ability to circumvent various types of regulation. Caves (1996) also outlines several areas of 
potential conflict — taxation and competition policy, bargaining over natural resource rents, and technology transfer issues. ${ }^{4}$

A bargaining approach is also adopted by Behrman and Grosse (1990) and Fagre and Wells (1982). Other examples of bargaining models include Bergsten, Horst, and Moran (1978) and Osland and Bjorkman (1998). Ramamurti (2001) adds to this literature and argues that the traditional bargaining model of MNC-host developing country relations is better understood as a two-tier, multiparty bargaining process. Tier 1 bargaining between the governments of host and home countries occurs bilaterally or through multilateral institutions. It produces macro rules on foreign direct investment (FDI) that affect micro negotiations in Tier 2 (the traditional bargaining model).

Brewer (1992) summarizes other underlying theoretical models used in the international business literature to frame the MNC-host government relationship. One of the models here is the 'Sovereignty at Bay' model, which was originally presented in Vernon's book (1971) of the same title and subsequently revised by Vernon $(1977,1981)$. The key proposition is that MNCs infringe on the sovereignty of governments in a nation-state system. Another model that explores the MNC- host country relationship is the 'dependency model.' This model assumes MNCs to be in a cooperative partnership with home governments (of industrial countries) and in an adversarial relationship with host governments (in developing countries). The latter governments, however, are in a relatively weak, dependent position. One of the key expositions of the dependency model is by Bamet and Muller (1974). Finally, Prahalad and Doz (1987) emphasize the diverse ways in which host governments restrict MNCs, though they also acknowledge that host governments 'occasionally' have positive, helpful effects on MNCs.

\footnotetext{
${ }^{4}$ Rugman and Verbeke (1998) build on this literature and argue that from the perspective of MNCs, governments increasingly do not unambiguously represent either a home or a host country, given the dispersed structure of subsidiaries.
} 


\section{Influence-based models}

Until recently, the exposition of MNC-host government relationships in the international business literature had two important gaps. First, the literature did not consider the disaggregated nature of the government. Second, the literature also did not account for dynamic interactions between government actors and how this might affect choice of MNC strategy in dealing with the government.

In more recent work, Henisz (2009) builds on influence-based models in political science and on social network theory to address several of these issues. There are two major theoretical antecedents of this literature. The first antecedent relates to the dynamic expected utility decision process developed by Bruce Bueno de Mesquita (de Mesquita, 1980, 1985; de Mesquita and Lalman, 1987, 1988), which allows for strategic interaction by utility maximizing autonomous actors over time to minimize their loss functions in a unidimensional policy space. The second theoretical antecedent relates to social network analysis (Wasserman and Faust, 1997). This literature represents government actors as embedded in a network structure that both enables and constrains their behavior. In related work, Henisz and Zelner (2010) outline the idea of 'influencers.' To quote the authors, 'Analysts (working for a multinational firm) constructed a network of influencers and modeled various points of entry into this system to identify target areas and the messages that would maximize their effect on the climate change debate.'

The topic of interactions and interdependencies between political actors has also been studied in the 'veto points' literature in political science. Scholars such as McNollgast (1987, 1989) and Weingast (1983) have long modeled how institutional veto points combine with politicians' electoral preferences to affect policy outcomes. A key insight here is that any political actor realizes that the final policy will lie within a range of policies acceptable to all 
other actors who have veto power. As a result, as Tsebelis (1995, 2003) outlines, the probability of policy change decreases as the number of political actors with veto power increases or the congruence (similarity of policy position of each veto player) decreases. The veto points framework has been studied in several contexts such as the development of electricity infrastructure development in the U.S. (Henisz and Zelner, 2004).

Building on this literature and drawing from areas such as transaction cost analysis, the theory of repeated games, and positive political theory, scholars such as Pablo Spiller and Mariano Tommasi (2007) forward the idea that public policy is the outcome of intertemporal transactions among political actors. Using insights from the theory of repeated games, they identify the conditions that are more likely to foster cooperative, credible, and adaptable policies as opposed to noncooperative, non-credible, volatile, or rigid policies. More specifically, they forward the idea that the transactions that political actors are willing and able to undertake will depend on the number and cohesiveness of the political actors involved, the intertemporal pattern of payoffs to the actors, etc. Spiller (1990) had earlier expanded this idea to include not only political actors, but also interest groups and other regulators. As the next section will outline in detail, we build on the idea of 'interest groups' in Spiller's (1990) work in thinking of the government landscape comprising of a 'periphery of influence.'

In addition to influence-based models in political science, we also draw insights from other literatures. There are several articles in the public policy literature that recognize the disaggregated nature of the government. The focus here is on networks comprising government actors (Agranoff and McGuire, 2001, 2003; O’Toole, 1997). Researchers such as Stevens and 
McGowan (1983) have described the complex structure of 'government' comprising federal, local, and municipal government actors. ${ }^{5}$

There is also a literature in corporate strategy that accounts for the disaggregated nature of the government and the idea that firms could try to directly influence government actors. Here, we note the work by Austin (1990). He acknowledges the disaggregated nature of the government and forwards an economic approach of how firms should interact with the government. His approach includes three steps-(1) political mapping, (2) assessment of congruency, and (3) designing the strategy. He also outlines four generic strategies in how firms can engage with government actors — alter (firm bargains and alters government policy), avoid (firm takes strategic moves to bypass risk of government action), accede (firm adjusts operations to comply with government requirements), and ally (firm insulates itself from risk out of government policy by creating strategic alliance) ${ }^{6}$

\section{THE ‘CORE-PERIPHERY’ FRAMEWORK}

Our 'core-periphery' framework builds on influence-based models in the political science and strategy literatures and extends it by formally disaggregating the government landscape into a set of 'core' actors who are involved in policy decision making and a set of 'peripheral' actors who

\footnotetext{
${ }^{5}$ The network structure of the government has been studied in the context of several theoretical concepts: Provan and Milward $(1991,1995)$ on governance structure and outcomes, Mandell (1999) on management styles and instruments, Agranoff and McGuire (2003) on collaborative instruments, Bardach (1998) on theories of collaborative leadership, Koppenjan and Klijn (2004) on management knowledge to deal with uncertainty, McGuire (2000) on management styles, and O'Toole and Meier (2001) on managerial strategies and behaviors.

${ }^{6}$ The first step in the framework (political mapping) offers a way to disaggregate the government into discrete actors, namely national level officials, bureaucrats, party officials, labor leaders, state-owned enterprises, and pressure groups. The political mapping step also includes designating the interests of each actor identified on the map. The second step of the framework (assessment of congruency) offers two analytical tools-the congruency assessment matrix and 'economic cost benefit analysis' (ECBA). The congruency assessment matrix offers an analytical way to identify areas of potential fit between a firms' resources and 'needs' of a government actor. The economic cost benefit analysis tool, however, provides a discounted cash flow-based framework to assess the attractiveness of different strategies a firm can follow in engaging with government actors. In the final step of the Austin framework, there are four generic strategies in how firms can engage with government actors.
} 
are not involved in decision making, but can influence the core. We then outline the mechanisms through which peripheral actors can influence the core.

Building on Tsebelis (1995), in our framework, we define the 'veto points core' as the set of state actors with veto power over the policy outcome of interest.

We also recognize that MNCs not only deal with state actors in the 'veto points core,' but they deal with several other state, quasi-state, and civil society actors as well. Quasi-state actors are not directly involved in policy setting, but may receive funding from a core government actor. Such actors may not have direct veto power over the policy decision in question, but they have formal as well informal influence over one or more actors in the 'veto points core.' We define the second set of state and civil society actors as forming the 'periphery of influence.'

\section{Mechanisms for how the periphery can influence the core}

There are two possible mechanisms for how the periphery can influence the core: (1) by changing the information set for the core actors and (2) by aligning the incentives of the core actors with the interests of the MNC in question.

Building on Spiller (1990), we posit that each core actor has its own information set. Peripheral actors can manipulate this information set in multiple ways. As an example, the peripheral actor can run pilots or proof of concepts that provide data or analyses supporting the claims that the MNC in question is making. This can, in turn, change the information set of the

core actors and position the core actors more favorably toward the MNC in question. There could also be a transfer of individuals from the periphery to the core. New individuals can bring new information to the core actors. This too can change the information set of the core actors in question. 
The MNC in question can also engage the periphery to help align the incentives of various core actors. Here we build on several critical insight in the veto points literature. As Tsebelis $(1995,2003)$ outlines, the probability of policy change decreases as the number of political actors with veto power increases or the congruence-i.e., the similarity of policy position of each veto player-decreases. As an example, difference in incentives among actors in the 'veto points core' can stem from competing for scarce resources (e.g., in a health care setting, the Ministry of Biotechnology might directly compete with the Ministry of Health for government resources to fund programs), from the structure of multiparty coalition governments (with one party controlling one of the key agencies and another party controlling yet another agency of interest), or from the misalignment in incentives between bureaucrats and politicians involved with actors in the 'veto points core.'

However, a single peripheral actor might be able to influence more than one core actor in question. As an example, the peripheral actor might have a resource sharing relationship with one of the core actors and an advisory relationship with another core actor. If the MNC is able to engage with the relevant peripheral actor, the peripheral actor, in turn, might be able to catalyze the process of the two core actors reaching agreement on the policy decision in question.

In summary, by engaging the periphery, the MNC could influence the core. If the influence is of a positive nature, it could help align the incentives of the core actors and/or change the information set of the core actors favorably toward the interests of the MNC. However as we will discuss in greater detail, there could be a negative influence from the periphery to the core as well. By engaging with peripheral actors whose incentives are not aligned with the core actors, the MNC could create negative influences in the core. 
We also posit that the core-periphery framework might be particularly useful in environments where there is regulatory uncertainty. In the absence of a well-defined regulatory framework, core government actors might have incomplete information to act on the policy decision in question. In such an environment, peripheral actors might have a particularly salient role in influencing the information set of core actors and/or in aligning incentives of multiple core actors.

\section{Operationalizing the framework}

To operationalize the framework, we employ three main analytical steps: (1) identifying the state and quasi-state civil society actors relevant to the MNC in question; (2) classifying the actors as being either in the 'veto points core' or in the 'periphery of influence;' and (3) identifying the mechanisms by which the actors in the periphery can influence actors in the core as well as other actors in the periphery.

Step 1 of the framework involves identifying the relevant state actors that an MNC interacts with. We conceive the 'government' as a network of interconnected state actorsgovernment departments, universities, public research labs, etc.

Step 2 in the framework is focused on identifying which actors reside in the 'veto points core' and which actors reside in the 'periphery of influence.' Identifying the core set of actors is relatively straightforward and is based on whether or not the individual actors have veto power over the policy decision in question. To identify the relevant set of peripheral actors, we offer the following conceptual framework - a peripheral actor is relevant if it is able to change the information set of the core actor or align the incentives of the core actors toward the policy interests of the MNC. Operationally, the MNC can identify relevant peripheral actors using the following three conditions: (1) a peripheral state, quasi-state, and civil society actor is relevant if 
it exchanges information with one or more core state actors on the policy decision in question (to achieve the 'changed information set' condition); (2) a peripheral actor is relevant if it exchanges resources (e.g., decision makers) with one or more core state actors (to achieve the 'changed information set' condition); and (3) a peripheral actor is relevant if it has a formal or informal reporting relationship to two or more of the relevant core actors. If a peripheral actor is connected to two or more core actors, it creates opportunities for the MNC to influence the periphery and align incentives in the core.

Step 3 involves using real data and identifying mechanisms of how the periphery can influence the core. Here, we identify reporting structures for each actor and map out information and resource linkages among the different actors. Peripheral actors can provide core actors with information related to the policy decision in question. Actors in the periphery can also exchange resources with actors in the core, and this could have an effect on the information set of the actors in the core. Examples of influence based on exchanging resources could include transfer of employees from the peripheral actor to the core actor. The peripheral actors can also exert influence on the core set of actors by shaping public opinion on the policy decision question.

To complete this analysis, we also identify whether actors in the periphery have any influence on other actors in the periphery. Here, we posit that peripheral actors can influence the core directly or indirectly through another peripheral actor. Figure 1 summarizes the core periphery framework.

INSERT FIGURE 1 HERE

\section{CLINICAL STUDY OF GLOBAL BIOTECHNOLOGY MULTINATIONAL}


In this section, we illustrate the core-periphery influence framework using a clinical study of Genzyme, a biotechnology MNC. As this section describes in detail, the strategy of Genzyme was to secure government reimbursement for orphan drugs focused on rare diseases. Our choice of Genzyme to illustrate the core-periphery framework is motivated by the regulatory uncertainty in the reimbursement of orphan drugs across emerging markets. Given the theoretical proposition that we stated earlier, in such an environment, the importance of peripheral actors in influencing the core becomes even more salient. In the Appendix, we document the evolution of orphan drug legislation in the United States and Europe. As the Appendix illustrates, the U.S. and European regulatory frameworks on orphan drug reimbursement evolved over several years. As of 2011, in several emerging markets, there is no well-defined legislative framework supporting government reimbursement for orphan drugs.

Our analysis is based on 32 in-depth interviews conducted with Genzyme executives from August 2008 to October 2010. Interviews were conducted with the CEO and other Genzyme executives at the corporate headquarters in Cambridge, Massachusetts, as well as executives in subsidiaries in Brazil, China, Costa Rica, France, India, and the United States. Using in-depth qualitative examples, we illustrate how the core-periphery framework works in three emerging markets-Brazil, China, and Costa Rica. In constructing the sample of countries for the in-depth case studies, we tried to account for heterogeneity in variables such as the size of the country, heterogeneity in how authoritarian versus democratic the regime is, relative importance of the federal versus provincial government actors, relative importance of civil society, etc. Here, we would like to acknowledge potential endogenity in constructing the sample. It is possible that the choice of market entry on the part of Genzyme was motivated by an ex ante sense of which host governments were more likely to support reimbursement of 
orphan drugs. However, our clinical study is in the methodological tradition of qualitative case study research by Yin (2003) and other researchers.

\section{Profile of Genzyme}

Genzyme had a modest beginning in 1981 as a supplier of enzymes, fine chemicals, and reagents to research labs and pharmaceutical companies. Since then, it has grown to become a leader in biotechnology, with revenues of almost $\$ 4$ billion in 2007. Genzyme's strategy was focused on developing orphan drugs for 'rare diseases,' i.e., diseases that affected a very small part of the patient population around the world. Though the diseases could be debilitating and even fatal, given the low incidence rates, drug development for such diseases did not attract proportionate funding from the mainstream pharmaceutical industry. Genzyme had started operations with a rare disease named Gaucher that affected fewer than six of every one million people, but was debilitating in the concerned patient population. Based on R\&D conducted by Dr. Roscoe Brady of the National Institute of Health (NIH) and subsequent clinical trials, Genzyme had reportedly estimated that if the 'orphan drug status was awarded' to its product for Gaucher called Ceredase, it could serve around 2,000 patients worldwide, with projected annual sales of $\$ 100$ million. ${ }^{7}$ In 1991, the U.S. Food and Drug Administration approved Ceredase for marketing in the United States. Subsequently Genzyme started venturing into other therapeutic areas. A key element of the strategy was to secure orphan drug-like status around the world where government agencies would partially or fully reimburse medication costs for patients who could not afford the costly medication. This element of Genzyme's' strategy brought it in close contact with governments around the world and in emerging markets such as Brazil, China, Costa Rica,

\footnotetext{
${ }^{7}$ Under the Orphan Drug Act of January 1983, companies doing research on rare diseases affecting fewer than 200,000 people in the United States were awarded tax breaks and marketing exclusivity on that drug for seven years post-approval.
} 
India, and elsewhere. ${ }^{8}$ Figure 2 documents the importance of international sales to Genzyme.

Figure 3 outlines the reliance Genzyme had on orphan drugs.

INSERT FIGURES 2 AND 3 HERE

\section{Case study: Genzyme in Brazil}

We follow the three steps illustrated in the previous section to illustrate the core-periphery framework in the case of Genzyme in Brazil.

\section{Background}

Genzyme opened its Brazilian subsidiary in 1997. By 2009, Brazil figured in the top five locations for Genzyme in terms of sales. Genzyme was also among the top 15 pharmaceutical companies of Brazil. The subsidiary had around 100 employees and sold 14 products from Genzyme's portfolio. In addition to having a sales team, the Brazilian operations supported clinical research (Phase 2 and Phase 3 trials). However, there was no manufacturing or direct R\&D being conducted in Brazil. As in other emerging markets, the cornerstone of Genzyme's strategy in Brazil was to secure government reimbursement for its drugs for patients who could not afford them. By 2009, of all Genzyme products, Cerezyme ${ }^{9}$ (the Gaucher product) was the only one federally funded in Brazil. Another product that was partially funded was Renagel. Other products were sold through hospitals and private doctors. However, sales of Cerezyme comprised a disproportionate share of Genzyme sales in Brazil.

\footnotetext{
${ }^{8}$ An anecdotal summary of the Genzyme strategy is outlined in the Harvard Business School cases titled 'Genzyme's Gaucher initiative: will global risk and responsibility' (2002) authored by Christopher A. Bartlett and Andrew McLean and 'Genzyme's CSR dilemma: how to play its HAND' (2009) authored by Christopher A. Bartlett, Tarun Khanna, and Prithwiraj Choudhury.

${ }^{9}$ Cerezyme was the new name of the Gaucher medication. The earlier name, used in a prior section, was Ceredase.
} 
The Brazilian subsidiary was started by a local doctor named Rogerio Vivaldi. Starting 1991, much prior to joining Genzyme, he was among the first doctors to treat the Gaucher disease in Brazil. In 1998, he was designated general manager for Genzyme in Brazil, with additional responsibility for all of Latin America. This was based on his success in creating an extremely successful program focused on alleviation of the Gaucher disease. By 2008, the program had enlisted 600 patients and the therapy was funded by the federal government. The next subsection describes the strategy being employed by Genzyme to secure federal funding for Gaucher and other drugs in its pipeline.

Gaucher is among five diseases that are reimbursed by the Brazilian federal government under the 'exceptional diseases' list. Other diseases on the list include TB, diabetes, hemophilia, and HIV.

The national health policy of Brazil is based on the Federal Constitution of 1988. This outlines that delivery of health care would be executed through a unified health system. The health system is a three-tier pyramid comprising the municipal, state, and federal levels. The role of the federal government was to outline broad direction in multi-year plans approved by the national congress for four-year periods. However, starting in 1996, execution of health care delivery (i.e., treating the patients) was to be done by the municipal governments. Policy and technical direction would come from the federal and state levels.

Being on the list of exceptional diseases allows for direct funding from the federal government no matter where the patient is treated. Genzyme initiated the process of trying to secure federal funding for Gaucher around the time José Serra, the mayor of Sao Paolo, was initiating widespread health care reform. This was during the presidency of Fernando Cardoso. Serra initiated the list of drugs for 'exceptional diseases' and the mantra for his reform process 
was drug efficacy. Until this point, Genzyme had been providing free Gaucher medication to a whole host of patients in Sao Paolo and elsewhere and had been focused on demonstrating the efficacy of its medication. Genzyme's strategy caught the attention of Serra, and this initiated the process of Gaucher getting on the list of 'exceptional diseases.'

As a Genzyme executive outlined in one of the field interviews, 'we had direct discussions with Serra and his health care officials. The focus was on talking about the disease and the efficacy of our drug - not on the price, nor on our commercial interests. Until that point, we were providing the drug for free for hundreds of patients, and the efficacy results were stunning. Other pharmaceutical companies, meanwhile, were focused on lobbying for commercial interests.'

However, getting the Gaucher drug enlisted was followed by skepticism in some quarters of the government. As one executive said, 'getting Gaucher on the list of exceptional drugs was not easy. It will be hard work to ensure that it sustainably stays on the list. Skeptics in the government point out that the federal government investment in Gaucher could be instead used to solve TB or a more widespread disease. Getting other drugs we have in the pipeline to be on the list is going to be a much bigger challenge.' Brazil followed a system where the list of exceptional drugs is reviewed and updated every three to four years. As Figure 4 indicates, several biologics had secured government reimbursement. However the pipeline of drugs waiting approval was also quite extensive. At the time of our field interviews, there were around 100 drugs from several pharmaceutical firms (including five drugs from Genzyme) that have been proposed as candidates for the list.

\section{INSERT FIGURE 4 HERE}


The next subsection outlines the strategy being employed by Genzyme to ensure that it got traction in discussions around updating the list of exceptional drugs. It also describes how this strategy relates to the core-periphery framework.

\section{Brazil: identifying the 'veto points core' and the 'periphery of influence'}

In terms of the core-periphery framework, we identify the key federal actors with direct veto power over decisions like updating the list of exceptional drugs. The main actor is the Ministry of Health. In addition there are seven federal actors relevant to various decisions of public health policy: (1) the National Health Surveillance Agency (Anvisa), created in 1999, is focused on the production and marketing of products and services subject to sanitary surveillance; (2) the National Health Insurance Agency (ANS), established in 1998 regulates providers of health insurance; (3) the Brazilian Blood, Products, and Biotechnology Company (Hemobras), established in 2004 is focused on the production of blood components; (4) the National Institute of Traumatology and Orthopedics (INTO), created in 1994 treats patients with orthopedic trauma; (5) the National Cancer Institute (INCA), established in 1938, provides free medical assistance to cancer patients; (6) the Oswaldo Cruz Foundation (Fiocruz) was set-up in 1900 and is focused on producing vaccines, research, education and field services; (7) the National Health Foundation (Funasa), responsible for carrying out sanitation work based on epidemiological, socioeconomic and environmental criteria.

Though all of these agencies were linked to the Ministry of Health, they had a fair degree of administrative independence and financial autonomy. As an example, Anvisa was managed by a board of directors made up of five members, a few of them being independent. As for Genzyme, the company realized early on that engaging with Fiocruz had the highest potential for creating positive influences with the Ministry of Health. 
Returning to the core-periphery framework, we outline the veto actors in deciding which drugs would make the list of exceptional diseases. The Ministry of Health was the formal decision maker and the key actor in the veto core. In addition, another core actor was the National Epidemiology Center (CENEPI). Decision making at the Ministry of Health was supported by analyses, data, and opinion from CENEPI, an agency of the National Health Foundation (Funasa). This actor coordinated the national epidemiological surveillance system and provided information on the incidence of various diseases using tools such as biostatistics, geographic information systems (GIS), etc. The two core actors were surrounded by the periphery of influence made up of seven interconnected federal agencies as outlined in the previous section. Of these seven, Genzyme decided to develop a deep engagement with Fiocruz. ${ }^{10}$ As the next subsection describes, officials at Genzyme realized that Fiocruz had deep links with both the Ministry of Health and CENEPI and had the potential to change the information set of these two core actors.

\section{Brazil: identifying the mechanisms for the periphery influencing the core}

Fiocruz is the largest science and technology institution in the health care area in Latin America.

The main campus is in Rio de Janeiro; this is also where the administrative headquarters of

Fiocruz and ten out of its 13 scientific units are based. Though traditionally focused on producing vaccines, research was identified as a key priority area for Fiocruz. Priority areas for research were identified as virology, epidemiology, immunity, and parasitology. In the area of

\footnotetext{
${ }^{10}$ Given the detailed steps of the core-periphery framework outlined in the previous section, the researchers and Genzyme executives identified all relevant peripheral actors based on the three conditions outlined-(1) a peripheral actor is relevant if it is able to exchange information with core actors; (2) a peripheral actor is relevant if there is transfer of resources (e.g., employees) from the peripheral actor to the core; and (3) a peripheral actor is relevant if it is connected to two or more core actors. Using text of the 'stated objectives' of each peripheral actor and interviews with the Genzyme country manager, we also triangulated to check if the incentives of the peripheral actor were aligned with the MNC in question. In this case, both Genzyme and Fiocruz wanted to work on medication for Chagas.
} 
research, Fiocruz had achieved a major breakthrough way back in 1909, when researcher Carlos Chagas isolated the parasite that caused the disease Chagas. ${ }^{11}$ In addition to identifying the parasite, he also established that the transmission vector was the Triatoma, a blood-sucking bug found in Brazil. Since then, developing a cure for Chagas was seen as a key priority for Fiocruz and its research efforts. Over the years, there were several attempts to develop a foolproof vaccine for Chagas, none of them being completely successful. Genzyme came to know about the Fiocruz focus on Chagas when an executive met a Fiocruz researcher at a conference. The Genzyme team sensed an opportunity for meaningful engagement here, based on developments in other parts of the world.

In March 2004, Genzyme had bought Ilex Oncology Inc., a biotechnology company focused on the treatment of bladder cancer, solid tumors, and other forms of cancer. But as part of its oncology repertoire, Ilex had on its shelves a drug called eflornithine which had been shown to have an unexpected yet positive effect on African trypanosomiasis (or sleeping sickness). This disease was very similar to Chagas and Genzyme sensed that it had something to offer to Fiocruz. In 2007, Rogerio Vivaldi proposed sending Fiocruz scientists to Genzyme's Waltham R\&D center to explore whether the Genzyme drug could be used as a starting point to develop medication for Chagas. In late-2008, after returning from his six months in Waltham, the first scientist sent from Fiocruz reported that the experience was a cultural eye opener in the process of drug development. Marcos, the Fiocruz scientist, was an expert in parasite biology and tracking the pathways of polyamine biosynthesis; in return, the Genzyme scientists had a lot to contribute in developing understanding of how to take basic science to new therapies and move them through the pharmaceutical development process.

\footnotetext{
${ }^{11}$ The Chagas disease is also known as American trypanosomiasis.
} 
The engagement with Fiocruz led to a whole host of benefits for Genzyme. The firm benefited when a senior executive at Fiocruz who was in charge of the Genzyme initiatives was transferred to the Ministry of Health. This led to positive influences in supporting Genzyme's claims for adding more of its drugs to the list of exceptional drugs. In terms of the core-periphery framework, this is an example of a peripheral actor (Fiocruz) influencing a core actor (the Ministry of Health) by exchanging resources (employees, in this case) and influencing the information set of the core actor.

There were other influences. Fiocruz was involved in provisioning hospitals and outpatient services and had a vast network of researchers. Genyzme could tap this network to collect data on incidence of diseases and efficacy of drugs in its pipeline. Framing this in terms of the core-periphery framework, this is an example of the peripheral actor (Fiocruz) influencing the core actor (CENEPI) by exchanging information, thus altering the information set of the core actor. Figure 5 summarizes the relevant government landscape for Brazil and the identification of core and peripheral actors.

\section{INSERT FIGURE 5 HERE}

\section{Case study: Genzyme in China}

In this section, we outline the interactions between Genzyme and the host government in China and study the interactions using the core-periphery framework.

\section{China: mapping the 'veto points core' and the 'periphery of influence'}

For China, the policy decision in question is the registration and reimbursement of new drugs. This is a four-step process where drugs have to be registered at the federal and provincial levels; 
the government and the MNC have to agree on acceptable price levels, the federal and state governments have to purchase the drugs for use in hospitals, and finally, the government has to agree to reimburse the cost of the drugs.

In terms of the core-periphery framework, the four relevant state actors with veto power are: (1) the State Food and Drug Administration (SFDA); (2) the Ministry of Health (MOH); (3) the Development and Reform Commission (DRC); and (4) the Human Resource and Social/Labor Security Agency (HRSLA).

Of these four key agencies, the SFDA and MOH have subagencies at each of the 31 provinces. The DRC has a subagency at the federal level (the national development and reform commission or NDRC) and subagencies in the key provinces. Similarly the HRSLA has subagencies in key provinces. Collectively, these four actors comprise the 'veto points core' in China.

The SFDA is responsible for registration of drugs and medical devices. The Ministry of Health is the governing body for health care delivery in the country and a key player in shaping major health care policies. Its provincial and municipal affiliates play a role in determining pricing for in-hospital medical services. The NDRC is responsible for budgeting the tendering process of drugs and medical devices. In turn, the local-level DRCs coordinate the tendering process for their respective provinces and cities. Finally, the HRLSA is responsible for preparing the catalogs of drugs eligible for government reimbursement at the country level. Local governments can make adjustments to the national catalog based on their budget situation and the local epidemic profile of the disease.

In addition, there are several other state and quasi-state actors that comprise the 'periphery of influence.' This includes the state-run hospitals. A key quasi-state civil society actor is the 
influential China Charity Federation (CCF). This is a government-organized 'NGO' or GONGO. ${ }^{12}$ Most of the CCF management at both the national and local levels is also staffed by former officials retired from China's Ministry of Civil Affairs (MCA). There are also administrative relations between the $\mathrm{CCF}$ on the one hand and the $\mathrm{MOH}$ and the SFDA on the other. The CCF is also staffed by several ex-government officials, including several ex-members of the seventh and ninth National People's Congress and ex-members of the Chinese Federation of Trade Unions.

The next step in our analysis is to track the interdependencies between the state actors related to reporting relationships, flow of information, or flow of resources. At the federal level, the four agencies are relatively independent. All four report to the state council presided by the Chinese premier and vice premier, but they have administrative independence in taking day-today decisions. Until recently the SFDA was independent from the MOH. However, due to quality control scams, around 2006 the Chinese government started folding the SFDA under the $\mathrm{MOH}$. The two other federal agencies are completely independent. At the provincial or municipal level, however, all provincial agencies report to the vice governor or vice mayor. Figure 6 outlines the relevant actors in the Chinese landscape.

\section{INSERT FIGURE 6 HERE}

\section{China: identifying the mechanisms for the periphery influencing the core}

Using the core-periphery framework, we then identified the presence of influences in the government network in China. This relates to the case where Genzyme helped the CCF establish an office to help patients receive Cerezyme, a drug for the rare disease Gaucher, free of cost. This joint health office also conducted free check health checkups for patients and was used to

\footnotetext{
${ }^{12}$ The term GONGO (government-organized NGO) has been used by China scholars such as Yang (2005).
} 
increase awareness of rare diseases. The partnership between Genzyme and the CCF was kicked off at the Great Hall in Beijing, and the ceremony was attended by officials from the Ministry of Health, the SFDA, physicians from across the country, and about 50 media agencies. As one of the Genzyme executives mentioned in an interview, 'for the first time in China, rare diseases were discussed in a high profile public forum and Genzyme received a lot of attention as the catalyst of this discussion.'

A direct fallout of this event was that six hospitals were certified by the CCF as 'designated hospitals for rare diseases.' Over time, the six certified hospitals will collect data on the efficacy of treating patients with Cerezyme and will document the results using SFDA rules and regulations. As part of the aid program, local CCF officials will also collect and keep on file the socioeconomic data for different patients, which can be used to support the reimbursement argument. In addition, physicians from the six hospitals may present their experiences with treating Gaucher patients and may provide testimonials supporting the efficacy of Cerezyme at academic meetings or at reimbursement hearings organized by local governments.

Using the core-periphery framework, this is an example of the peripheral actor (CCF) influencing the core actors (SFDA, $\mathrm{MOH}$, and other core actors) by collating new data and changing their information set. This is also an example of a single action with a peripheral actor leading to positive influences with multiple core actors. Given the interlinkages between the CCF and SFDA/MOH, there is a direct influence from the CCF to the SFDA and the MOH. The interlinkages between the state-run hospitals and the HRSLA/NDRC provides an example of a peripheral actor (the $\mathrm{CCF}$ ) influencing actors in the veto core with the help of another peripheral actor (state-run hospitals).

\section{Case study: Genzyme in Costa Rica}


The case study of Genzyme in Costa Rica illustrates the role that civil society actors like the civil ombudsman and civil courts can play in influencing policy decision making by core government actors.

\section{Background: health care system in Costa Rica}

Several scholarly articles describe the health care system in Costa Rica and outline the factors contributing to its success. Connolly (2002) describes the health care system in Costa Rica as one of the 'world's most successful universal health care systems' where '100 percent of the population is given equal comprehensive public health insurance with equal access to services.'

Connolly (2002) then traces the antecedents of this success, and to quote the author:

'In 1941 social security legislation was passed in Costa Rica, establishing the Costa Rican Bureau of Social Security (CCSS). This legislation set the provisions for medical insurance that through the gradual expansion of the CCSS would eventually become a universal health insurance system. Costa Rica wrote a new constitution in 1949. The most significant component of the Constitution was the abolishment of a national army. This opened funding and allowed more attention to go toward social programs, such as education and health...The General Health Law of 1973 placed all health treatment services, including all health care areas and hospitals, under the control of the national social security program. In the next decade public health care coverage extended to reach 78 percent of the population in 1982. By this point, all those employed, regardless of their socioeconomic status, received health care. The Ministry of Health (MOH), which was established in 1907, at this time was responsible for public health programs such as prevention and promotion, and provided primary care for the uninsured. The MOH and the CCSS, working together to provide national health care, continued to refine their roles. In the early 1990s the MOH turned over primary health care provision responsibilities to the CCSS. The MOH has since been in charge of all public health programs, and the CCSS has been in charge of all health provision programs.'

There are several other academic articles that study the dramatic success of the Costa Rican health care system, especially in comparison to its geographic neighbors. ${ }^{13}$

\section{The core-periphery framework in Costa Rica}

\footnotetext{
${ }^{13}$ Rosero-Bixby (2004) assembles a geographic information system (GIS) to assess the equity in access to health care by Costa Ricans. The data shows substantial improvements in access (and equity) to outpatient care from 1994 to 2000. The author concludes that these improvements are linked to the health sector reform implemented since 1995. The share of the population whose access to outpatient health care (density indicator) was inequitable declined from 30 percent to 22 percent in pioneering areas where reform began in 1995-96.
} 
The two core government entities involved in approving reimbursement for any new drug in Costa Rica are the Ministry of Health (MOH) and the Department of Medicines and Therapeutics within the Social Security Organization. Under the existing legislation, Genzyme was not allowed to formally promote any of its medication to these entities, given that the medication was not formally registered.

However, a key peripheral player in this case was the medical genetics department at the Universidad de Costa Rica School of Medicine. Though Genzyme could not legally promote its medication to doctors in Costa Rica, it was permissible, for example, to create awareness about rare diseases like Gaucher by talking to doctors affiliated to the medicinal genetics department.

In 1996, Dr. Manuel Saborio Rocafort of the medical genetics department came across a patient who was diagnosed as having Gaucher. However, a committee comprising members of the $\mathrm{MOH}$ and Social Security Organization decided not to approve reimbursement for the expensive medication that the patient would require. To quote The Boston Globe (2009: PG), one of the key members on this committee commented that Costa Rica had '600,000 hypertensive patients, 120,000 diabetics,' and 'that's where they set the priorities.'

However, at this stage, the patient and her family reached out to a peripheral civil society player, the national ombudsman. This entity was an intermediary for filing lawsuits representing common people. The case reached Costa Rica's constitutional court in July 2003, and the judgment was in favor of reimbursing medication for the patient. At the hearing, Dr. Saborio testified about the diagnosis of the patient and the courts ruled that, under the universal health care system of Costa Rica, the MOH and the Social Security Organization had to reimburse the medication for Gaucher. 
In summary, the Costa Rica case study illustrates the role that civil society actors like courts can play in affecting policy decision making by core actors in the government network.

\section{DISCUSSION}

In this paper, we draw upon an emerging literature focused on influence models to study multinational firm-host government relationships. We add to this literature by proposing a stylized framework - the ‘core-periphery' framework - that analyzes how an MNC can influence peripheral actors to influence the core set of government actors. A key contribution of our paper is the illustration of specific mechanisms through which the periphery can influence the core. Our understanding is that prior literature has treated veto points as mostly exogenous and a function of the inherited structure of policy making. However, we posit that peripheral players are able to influence the incentives and/or the information set of the actors who have veto power.

Yet another contribution is the use of extensive case studies involving a biotechnology multinational across emerging markets. In summary, we illustrate that the core-periphery framework works across multiple emerging markets with heterogeneity in country size, institutional differences, etc.

An important consideration of our work is the level of analysis we employ to conceptually understand how MNCs should engage government actors. The literature in political science and strategy disaggregates the government landscape into individual actors in drawing out influence maps. Our core-periphery framework does the same, but we reaggregate the disparate government actors that might have been excessively disaggregated by prior work. In other words, our claim is that disaggregating the government landscape into a 'core' and a 'periphery' is sufficiently parsimonious, at least at the conceptual level. 
There are two other important considerations in using this framework. First, influences from the core to the periphery could either be positive or negative. All three examples presented in this paper are focused on positive influences. However, it is possible that by engaging the wrong set of peripheral actors, MNCs can create negative influences in the core. Anecdotally, executives at the MNC we studied recall an example of a negative externality from a large emerging market. In that country, the federal government comprised several coalition partners with the core actor managed by a particular member of the coalition. However, the company engaged yet another actor, a peripheral actor in this case, and the peripheral actor in question was managed by a different member of the coalition. In addition, there were significant and tacit differences in incentives between the two members of the coalition. Ex ante, these differences in incentives were not observable to the MNC in question. As a result, engaging the peripheral actor led to long-term negative influences in the core.

Second, a key insight of our framework is that in addition to considering pure state actors, we also consider quasi-state or even civil society actors, e.g., the national ombudsman in Costa Rica and a government-affiliated NGO in China, who may be influential in the government network. Building on the corporate social responsibility (CSR) literature, we posit that for MNCs, doing the responsible thing socially could have a fairly direct instrumental benefit in the government landscape. ${ }^{14}$

Finally, a key strategic implication of our framework is in thinking about how multinationals can engage host governments in the backdrop of regulatory uncertainty and

\footnotetext{
${ }^{14}$ In fact, Carroll (1994) presents results from a survey of 50 academic leaders in the field of CSR on what the priorities should be for the CSR field. While 21.5 percent academic leaders thought that the CSR field should be focused on the issue of business ethics and 16.1 percent academics voted for studying international social issues, only 9.8 percent of the scholars felt the CSR field should focus on studying how CSR relates to businessgovernment relationships. However, as our case studies from Genzyme across emerging markets show, interactions between MNCs and civil society actors can have significant influences in the MNC-government landscape.
} 
'emergent institutions.' Regulatory uncertainty might stem from the introduction of new and untested products (e.g., orphan drugs) or from technological discontinuity, etc. Henisz and Zelner (2005) study MNC-host government engagement in the backdrop of emergent institutions and conclude that 'the maturity of an emergent institution, its initial design process, its susceptibility to framing and degree of consistency with existing reference points' are 'crucial determinants of political risk' for an MNC. Building on this, we argue that in the backdrop of regulatory uncertainty and emergent institutions, engaging peripheral actors might be particularly important to the success of multinationals in emerging markets.

\section{ACKNOWLEDGEMENTS}

We thank Jay Barney, Tim Devinney, Jonathan Doh, Witold Henisz, Xavier Martin, Lilach Nachum, Eleanor Westney, and participants at the Global Strategy Journal (GSJ) launch conference and the seminar series at the University of Tilburg, Netherlands, for useful comments on a previous draft. We specially thank Jean Boddewyn for extensive feedback on a previous draft. Several executives at Genzyme have generously given their time. The usual disclaimer applies. 


\section{Figure 1. Core-periphery influence framework}

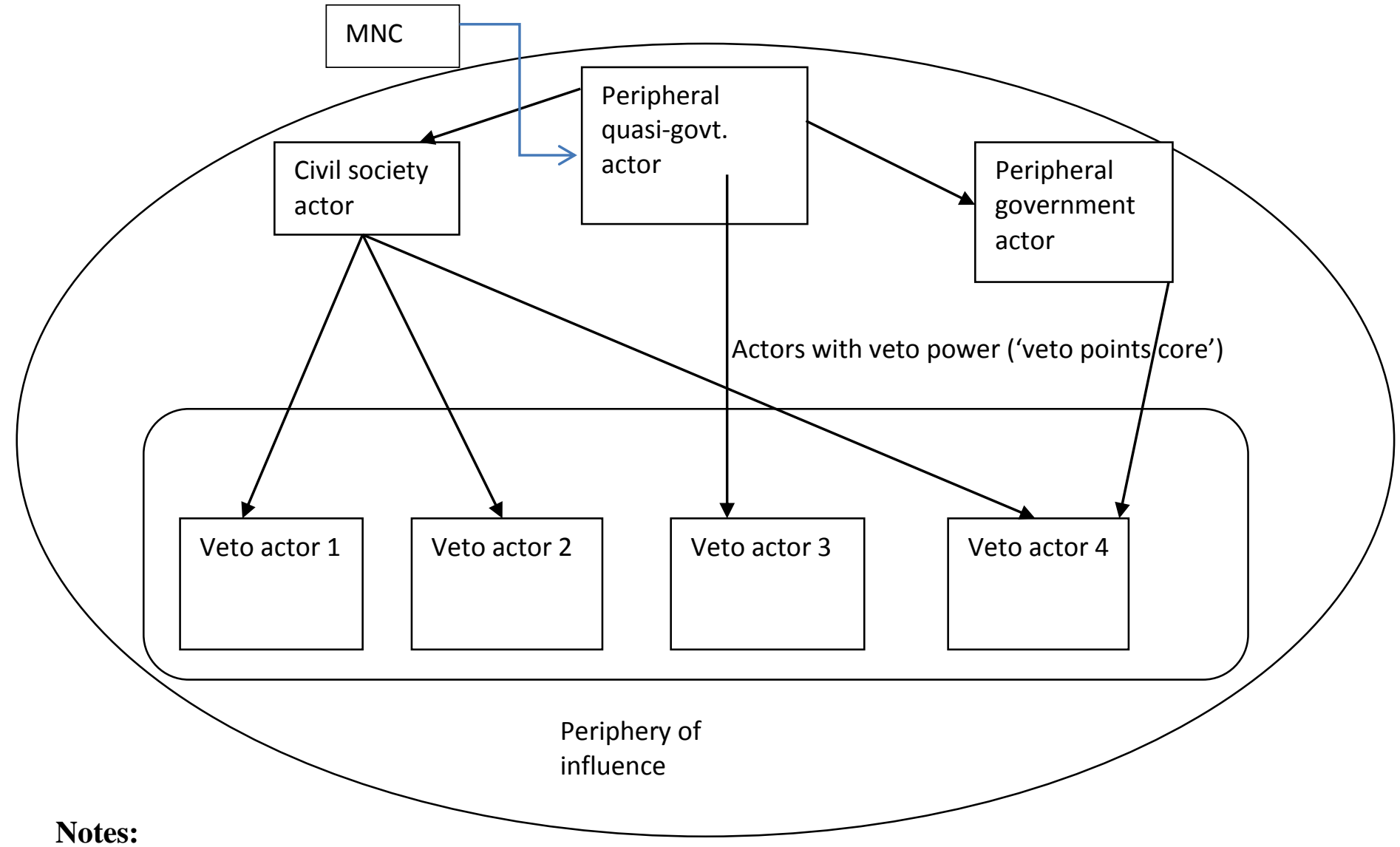

1. This graphic illustrates the core-periphery framework. We build on the 'veto points' literature in the political science and public policy literatures. Veto points refer to actors in the government decisionmaking process that can veto a policy change (Tsebelis, 1995).

2. In the core-periphery framework, we build an additional layer of government and quasi-government civil society actors on top of the 'veto points core.' We call this layer 'periphery of influence' (the outer circle). Peripheral actors do not directly veto the policy decision, but influence other actors in the veto points core. In this case, a government-affiliated NGO has direct influence on Veto Actor 3 and indirect influence on other actors in the veto points core through other actors in the periphery.

3. Our key insight is the following: scholars in the veto points literature have long recognized that the probability of policy acceptance decreases as the number of political actors with veto power increases or the congruence decreases. Achieving congruence in the core may be difficult given the low levels of coordination between veto actors. However, actors in the 'periphery of influence' might have multiple direct and indirect linkages to actors in the 'veto points core.'

4. If the MNC has a positive relationship with a peripheral actor (the NGO in this case), it might facilitate greater agreement among actors in the core and might catalyze the policy change. 
Figure 2. International revenues at Genzyme

\begin{tabular}{|l|l|l|l|l|l|l|l|l|l|l|}
\hline & 2009 & 2008 & 2007 & 2006 & 2005 & 2004 & 2003 & 2002 & 2001 & 2000 \\
\hline $\begin{array}{l}\text { Revenues } \\
\text { from } \\
\text { outside the } \\
\text { U.S. } \\
\begin{array}{l}\text { (U.S. \$ } \\
\text { billion) }\end{array}\end{array}$ & 2.14 & 2.34 & 1.82 & 1.46 & 1.22 & 0.99 & 0.74 & 0.52 & 0.45 & 0.31 \\
\hline $\begin{array}{l}\text { Percentage } \\
\text { of total } \\
\text { revenue }\end{array}$ & $48 \%$ & $51 \%$ & $48 \%$ & $46 \%$ & $45 \%$ & $45 \%$ & $44 \%$ & $40 \%$ & $37 \%$ & $42 \%$ \\
\hline
\end{tabular}

Notes:

- The source of this data is the U.S. Securities and Exchange Commission FORM 10-K for Genzyme.

- As the data shows, a substantial portion of the total revenue at Genzyme was from outside the United States. 
Figure 3. Product portfolio at Genzyme and focus on orphan diseases

Major current products ranked by sales*

\begin{tabular}{|l|l|l|l|}
\hline Product name & Disease/condition & $\begin{array}{l}\text { Is the medication } \\
\text { for an 'orphan } \\
\text { disease?' }\end{array}$ & Revenue in 2007 \\
\hline Cerezyme $^{\circledR}$ & Gaucher disease & Yes & \$1.13 billion \\
\hline Renagel $^{\circledR}$ & End-stage renal disease & No & \$ \\
\hline Fabrazyme $^{\circledR}$ & Fabry disease & Yes & \$424 million \\
\hline Synvisc $^{\circledR}$ & Osteoarthritis of the knee & No & \$242 million \\
\hline
\end{tabular}

*List not complete.

Notes:

- Source: Genzyme.

- As this exhibit shows, a large fraction of Genzyme's revenue comes from selling medications for orphan (rare) diseases. Most of this medication is distributed through peripheral sources in various emerging markets. 
Figure 4. List of biologics that secured government reimbursement in Brazil

\begin{tabular}{|c|l|}
\hline \multicolumn{1}{|c|}{ Launch time } & \multicolumn{1}{|c|}{ Product } \\
\hline 1992 & Neupogen \\
\hline 1997 & Rebif \\
\hline 1999 & Herceptin \\
\hline 1999 & MabThera \\
\hline 2001 & Glivec \\
\hline 2001 & PegIntron \\
\hline 2001 & Remicade \\
\hline 2003 & Enbrel \\
\hline 2004 & Humira \\
\hline 2005 & Baraclude \\
\hline 2005 & Xolair \\
\hline 2006 & Nexavar \\
\hline 2006 & Sutent \\
\hline 2007 & Avastin \\
\hline 2007 & Erbitux \\
\hline 2007 & Orencia \\
\hline
\end{tabular}

Source: IMS Health. 
Figure 5. Core and peripheral actors in Brazil

\begin{tabular}{|l|l|l|l|}
\hline Actor & Classification & Reporting & Role \\
\hline Ministry of Health (MOH) & Core actor & $\begin{array}{l}\text { Federal } \\
\text { government }\end{array}$ & $\begin{array}{l}\text { Approves the list of } \\
\text { 'exceptional drugs' eligible } \\
\text { for federal reimbursement }\end{array}$ \\
\hline CENEPI & Core actor & $\mathrm{MOH}$ & $\begin{array}{l}\text { Manages the national } \\
\text { epidemiological surveillance } \\
\text { system and provides } \\
\text { information on the incidence } \\
\text { of various diseases using } \\
\text { tools such as biostatistics, } \\
\text { GIS, etc. }\end{array}$ \\
\hline Fiocruz & $\begin{array}{l}\text { Peripheral } \\
\text { actor }\end{array}$ & $\mathrm{MOH}$ & $\begin{array}{l}\text { Focused on producing } \\
\text { vaccines, research, education, } \\
\text { and field services }\end{array}$ \\
\hline Anvisa & $\begin{array}{l}\text { Peripheral } \\
\text { actor }\end{array}$ & $\mathrm{MOH}$ & $\begin{array}{l}\text { Production and marketing of } \\
\text { products and services subject } \\
\text { to sanitary surveillance }\end{array}$ \\
\hline INTO & $\begin{array}{l}\text { Peripheral } \\
\text { actor }\end{array}$ & $\begin{array}{l}\text { POH } \\
\text { actor }\end{array}$ & $\begin{array}{l}\text { Peripheral } \\
\text { actor } \\
\text { orthopedic trauma }\end{array}$ \\
\hline Hemobras & $\mathrm{MOH}$ & $\mathrm{MOH}$ & $\begin{array}{l}\text { Focused on the production of } \\
\text { blood components }\end{array}$ \\
\hline ANS & $\begin{array}{l}\text { Regsistance to cancer patients } \\
\text { insurance }\end{array}$ \\
\hline
\end{tabular}


Figure 6. Core and peripheral actors in China

\begin{tabular}{|c|c|c|c|}
\hline Actor & Classification & Reporting & Role \\
\hline $\begin{array}{l}\text { State Food and Drug } \\
\text { Administration (SFDA) at } \\
\text { the federal level and in } 31 \\
\text { provinces }\end{array}$ & Core actor & $\begin{array}{l}\text { State council/ } \\
\text { vice governor/ } \\
\text { vice mayor of } \\
\text { province }\end{array}$ & $\begin{array}{l}\text { Registration of drugs and } \\
\text { medical devices }\end{array}$ \\
\hline $\begin{array}{l}\text { Ministry of Health (MOH) } \\
\text { at the federal level and in } 31 \\
\text { provinces }\end{array}$ & Core actor & $\begin{array}{l}\text { State council / } \\
\text { vice governor/ } \\
\text { vice mayor of } \\
\text { province }\end{array}$ & $\begin{array}{l}\text { Determines the of medical } \\
\text { services at federal level }\end{array}$ \\
\hline $\begin{array}{l}\text { The Development and } \\
\text { Reform Commission at the } \\
\text { federal level (NDRC) and at } \\
\text { key provinces }\end{array}$ & Core actor & $\begin{array}{l}\text { State council / } \\
\text { vice governor/ } \\
\text { vice mayor of } \\
\text { province }\end{array}$ & $\begin{array}{l}\text { Responsible for the tendering } \\
\text { of drugs and medical devices }\end{array}$ \\
\hline $\begin{array}{l}\text { The Human Resource and } \\
\text { Social/Labor Security } \\
\text { Agency (HRLSA) at the } \\
\text { federal level and in key } \\
\text { provinces }\end{array}$ & Core actor & $\begin{array}{l}\text { State council / } \\
\text { vice governor/ } \\
\text { vice mayor of } \\
\text { province }\end{array}$ & $\begin{array}{l}\text { Responsible for preparing the } \\
\text { catalog of drugs eligible for } \\
\text { government reimbursement }\end{array}$ \\
\hline Provincial hospitals & $\begin{array}{l}\text { Peripheral } \\
\text { actor }\end{array}$ & $\begin{array}{l}\text { Vice governor/ } \\
\text { vice mayor of } \\
\text { province }\end{array}$ & \\
\hline $\begin{array}{l}\text { The China Charity } \\
\text { Foundation (CCF) }\end{array}$ & $\begin{array}{l}\text { Peripheral } \\
\text { actor }\end{array}$ & $\begin{array}{l}\text { Ministry of civil } \\
\text { affairs }\end{array}$ & $\begin{array}{l}\text { Responsible for providing } \\
\text { medication to the poor }\end{array}$ \\
\hline
\end{tabular}




\section{REFERENCES}

Agranoff R. 2007. Managing Within Networks: Adding Value to Public Organizations.

Georgetown University Press: Washington, D.C.

Agranoff R, McGuire M. 2001. Big questions in public network management

research. Journal of Public Administration Research and Theory 11(3): 295-326.

Austin JE. 1990. Managing in Developing Countries. Free Press: New York.

Bardach E. 1998. Getting Agencies to Work Together: The Practice and Theory of Managerial Craftsmanship. Brookings Institution Press: Washington, D.C.

Barnett R, Muller RE. 1974. Global Reach. Simon \& Schuster: New York.

Bartlett CA, Ghoshal S. 1989. Managing Across Borders. Harvard Business School Press:

Boston, MA.

Behrman JN, Grosse RE. 1990. International Business and Governments: Issues and Institutions. University of South Carolina Press: Columbia, SC.

Boddewyn J. 1988. Political aspects of MNE theory. Journal of International Business Studies 19(3): 341-363.

Boddewyn J. 2005. Early U.S. business school literature (1960-1975) on international businessgovernment relations: its twenty-first century relevance. In International Business and Government Relations in the 21 st Century, Grosse RE (ed). Cambridge University Press: New York; 25-47.

Brandenburger AM, Nalebuff BJ. 1996. Co-opetition. Currency-Doubleday: New York.

Brewer TL. 1992. An issue-area approach to the analysis of MNE-government relations. Journal of International Business Studies 23(2): 295-309. 
Buckley P, Casson M. 1988. The theory of cooperation in international business. In Cooperative Strategies in International Business, Contractor FJ, Lorange P (eds). Lexington Books: Toronto, Canada; 31-34.

Carroll AB. 1999. Corporate social responsibility: evolution of a definitional construct. Business Society 38: 268-295.

Caves RE. 1982. Multinational Enterprise and Economic Analysis. Cambridge University Press: New York.

Caves RE. 1996. Multinational Enterprise and Economic Analysis (2nd edn). Cambridge University Press: New York.

Choudhury P, Khanna T. 2010. Privatization of innovation: evidence from India's state-owned laboratories. Working paper available at: http://papers.ssrn.com/sol3/papers.cfm?abstract_id=1429001 (accessed 21 October 2010).

Connolly G. 2002. Costa Rican health care: a maturing comprehensive system. Working paper, Tulane University. Available at: http://www.cehat.org/rthc/paper5.htm (accessed 21 October 2010).

Dastidar SG, Fisman R, Khanna T. 2008. Testing limits to policy reversal: evidence from Indian privatizations. Journal of Financial Economics 89(3): 513-526.

de Mesquita BB. 1980. An expected utility-theory of international conflict. American Political Science Review 74(4): 917-931.

de Mesquita BB. 1985. The war trap revisited: revised expected utility model. American Political Science Review 79(1): 156-177.

de Mesquita BB, Lalman D. 1987. Modeling war and peace. American Political Science Review 81(1): 221-230. 
de Mesquita BB, Lalman D. 1988. Empirical support for systemic and dyadic explanations of international conflict. World Politics 41(1): 1-20.

Dunning JH. 1995. Multinational Enterprises and the Global Economy. Addison-Wesley: Reading, MA.

Dunning JH. 1998. An overview of relations with national governments. New Political Economy 3(2): $280-284$.

Fagre N, Wells LT Jr. 1982. Bargaining power of multinationals and host governments. Journal of International Business Studies 13(2): 9-23.

Henisz WJ. 2009. Preferences, structure, and influence: the engineering of consent. Working paper, University of Pennsylvania.

Henisz WJ, Zelner BA. 2005. Legitimacy, interest group pressures, and change in emergent institutions: the case of foreign investors and host country governments. Academy of Management Review 30(2): 361-382.

Henisz WJ, Zelner BA. 2006. Interest groups, veto points, and electricity infrastructure deployment. International Organization 60(1): 263-286.

Henisz WJ, Zelner BA. 2010. The hidden risks in emerging markets. Harvard Business Review 88(4): 88-95.

Kobrin S. 1982. Managing Political Risk Assessment: Strategic Responses to Environmental Changes. University of California Press: Berkeley, CA.

Koppenjan J, Klijn E-H. 2004. Managing Uncertainties in Networks. Routledge: London, U.K.

Megginson WL, Netter JM. 2001. From state to market: a survey of empirical studies on privatization. Journal of Economic Literature 39(2): 321-389. 
Osland G, Bjorkman I. 1998. MNC-host government interaction: government pressures on MNCs in China. European Management Journal 16(1): 91-100.

O’Toole LJ Jr., Meier KJ. 2001. Managerial strategies and behavior in networks. Journal of Public Administration Research and Theory 11(3): 271-294.

Porter ME. 1990. The Competitive Advantage of Nations. Free Press: New York.

Prahalad CK, Doz YL. 1987. The Multinational Mission. Free Press: New York.

Provan KG, Milward HB.1991. Institutional-level norms and organizational involvement in a service-implementation network. Journal of Public Administration Research and Theory 1(4): 391-417.

Provan KG, Milward HB. 1995. A preliminary theory of interorganizational effectiveness: a comparative study of four community mental health systems. Administrative Science Quarterly 40(1): 1-33.

Ramamurti R. 2001. The obsolescing ‘bargaining model?’ MNC-host developing country relations revisited. Journal of International Business Studies 32(1): 23-40.

Reich RB. 2009. Government in your business. Harvard Business Review 87(7/8): 94-99.

Rosero-Bixby L. 2004. Spatial access to health care in Costa Rica and its equity: a GIS-based study. Social Science \& Medicine 58(7): 1271-1284.

Rugman AM, Verbeke A. 1998. Multinational enterprises and public policy. Journal of International Business Studies 29(1): 115-136.

Spiller PT. 1990. Politicians, interest groups, and regulators: a multiple-principals agency theory of regulation, or 'let them be bribed.' Journal of Law and Economics 33(1): 65-101.

Spiller PT, Tommasi M. 2007. The Institutional Foundations of Public Policy in Argentina. Cambridge University Press: New York. 
Stevens JM, McGowan RP. 1983. Managerial strategies in municipal government organizations. Academy of Management Journal 26: 527-534.

The Boston Globe. 2009. One girl's hope, a nation's dilemma. Available at: http://www.boston.com/news/world/latinamerica/articles/2009/06/14/one_girls_hope_a_n ations_dilemma/?page=full (accessed 21 October 2010).

Tsebelis G. 1995. Decision making in political systems: veto players in presidentialism, parliamentarism, multicameralism, and multipartyism. British Journal of Political Science 25(3): 289-325.

Tsebelis G. 2003. Veto Players: How Political Institutions Work. Princeton University Press and Russell Sage Foundation: Princeton, NJ.

Vernon R. 1971. Sovereignty at Bay: The Multinational Spread of U.S. Enterprises. Basic Books: New York.

Vernon R. 1977. Storm over the Multinationals. Harvard University Press: Cambridge, MA.

Vernon R. 1981. 'Sovereignty at Bay:' ten years after. International Organization Summer: 517529.

Wasserman S, Faust K. 1997. Social Network Analysis: Methods and Applications (reprinted with corrections). Cambridge University Press: New York.

Weingast BR, Moran MJ. 1983. Bureaucratic discretion or congressional control? Regulatory policymaking by the Federal Trade Commission. Journal of Political Economy 91(5): $765-800$.

Yang G. 2005. Environmental NGOs and institutional dynamics in China. The China Quarterly 181: 46-66. 
Yin RK. 2003. Case Study Research, Design, and Methods (3rd edn). SAGE Publications:

Thousand Oaks, CA. 


\section{APPENDIX}

\section{Evolution of orphan drug legislation in the United States and Europe UNITED STATES}

In the case of the U.S., orphan drugs are defined as drugs targeted at the cure of rare diseases affecting less than 200,000 individuals. Congress passed the Orphan Drugs Act in 1983 to encourage the development of such drugs. The act provided a three-pronged incentive to the manufacturers of orphan drugs: (1) a seven-year exclusivity to market the drug; (2) a tax credit of 50 percent of the cost of conducting human clinical trials; and (3) federal research grants for clinical testing of new therapies to treat or diagnose rare diseases.

In 1997, Congress amended the act and added another incentive by granting an exemption from the drug application fee charged by the Food and Drug Administration. The act has arguably stirred the development of new orphan drugs over the years. There were only 38 approved orphan drugs before the act and 1,129 orphan drug designations got implemented until 2004. The orphan products department has reviewed more than 1,400 and funded more than 500 studies.

\section{EUROPE}

The European regulation for orphan drugs was proposed in 1998 and brought to force in 2000. The definition of the rare disease in the European Union is a disease that affects less than five in every 10,000 people. The EU legislation provides the following benefits: (1) ten-year market exclusivity; (2) protocol assistance; and (3) access to the centralized procedure for marketing authorization. 
Current legislation says the sponsor of an orphan medicinal product shall be eligible to a total or partial fee reduction once the decision on orphan medicinal product designation has been granted to that sponsor by the European Commission.

Since its inception in 2000, the orphan drug legislation has seen more than 1,000 applications for orphan drug status. The impact of the legislation can be judged by the fact that around 2.5 million people stand to benefit from this legislation. 